\title{
Limb Revascularization in Patients with Diabetes Mellitus
}

\author{
L.A. Bokeria' ${ }^{1}$, V.S. Arakelyan ${ }^{1}$, V.G. Papitashvili ${ }^{1}$, Sh.Sh. Tsurtsumiya ${ }^{2}$ \\ ${ }^{1}$ Sechenov University, Moscow, Russian Federation \\ 2. Bakulev Scientific Center of Cardiovascular Surgery, Moscow, Russian Federation
}

\begin{abstract}
The review describes morbidity, mortality and possible complication rates for diabetic patients with peripheral arteries disease. The article demonstrates the modern tendency in the surgical treatment of peripheral arteries atherosclerosis, shows and compares worldwide results of endovascular and open revascularization. The authors have assessed the risk of amputation for patients with diffuse peripheral arteries disease and described basic treatment principals for better chronic ischemic ulcer healing.
\end{abstract}

Key words: peripheral artery disease, diabetes mellitus, stenting, bypass surgery, trophic ulcer, healing

Author Contributions. All authors were equally involved in writing the review.

Conflict of Interest Statement. The authors declare that the research was conducted in the absence of any conflict of interest. Received 08.11.2019. Accepted 09.12.2019

For citation: Bokeria LA, Arakelyan VS, Papitashvili VG, Tsurtsumiya Sh Sh. Limb Revascularization in Patients with Diabetes Mellitus. RUDN Journal of Medicine. 2019 Dec; 23 (4): 349-363. DOI: 10.22363/2313-0245-2019-23-4-349-363

\section{Реваскуляризация конечности у больных с сахарным диабетом}

\author{
Л.А. Бокерия ${ }^{1}$ В.С. Аракелян ${ }^{1}$, В.Г.Папиташвили ${ }^{1}$, Ш.Ш. Цурцумия ${ }^{2}$ \\ ${ }^{1}$ Первый Московский государственный медицинский университет \\ им. И.М. Сеченова, Москва, Российская Федерация \\ ${ }^{2}$ НМИЦ сердечно-сосудистой хирургии им. А.Н. Бакулева, Москва, Российская Федерация
}

\begin{abstract}
Аннотация. В обзоре литературы представлены данные о заболеваемости, летальности и возможных осложнениях заболеваний периферических артерий с сахарным диабетом. Данная работа посвящена оценке современных тенденций в области хирургического лечения атеросклероза артерий нижних конечностей. В ней представлены мировые результаты в сравнении
\end{abstract}

Bokeria LA, Arakelyan VS, Papitashvili VG, Tsurtsumiya ShSh., 2019

(c) () This work is licensed under a Creative Commons Attribution 4.0 International License

https://creativecommons.org/licenses/by/4.0/ 
эндоваскулярного и открытого метода реваскуляризации. Дата оценка рискам потери конечности при диффузном поражении артерий, а так же приведены основные принципы, которые необходимо учитывать для заживления конечности при трофических язвах.

Ключевые слова: заболевания периферических артерий, сахарный диабет, стентирование, шунтирование, трофическая язва, заживление

Вклад авторов. Все авторы были в равной степени вовлечены в написание обзора.

Заявление о конфликте интересов. Авторы заявляют, что исследование проводилось при отсутствии какого-либо конфликта интересов.

Поступила 08.11.2019. Принята 09.12. 2019

Для цитирования: Бокерия Л.А., Аракелян В.С., Папиташвили В.Г., Цурцумия Ш.Ш. Реваскуляризация конечности у больных с сахарным диабетом // Вестник Российского университета дружбы народов. Серия: Медицина. 2019. Т. 23. № 4. C. 349 -363. DOI: 10.22363/2313-0245-2019-23-4-349-363

Up to date, more than 170 million people worldwide suffer from diabetes mellitus (DM). By 2030, according to the vast majority of experts, in the coming years the number of patients will increase up to 300 million [1]. DM is the main risk factor for the development of peripheral arterial disease (PAD) [2]. It is proved that the presence of diabetes increases the risk of vascular complications 5 times relative to patients without it. In this regard, all patients with diabetes need to conduct diagnostic tests of all vascular arterial pools in case of damage to at least one of them. This approach helps to reduce the frequency of complications from surgical interventions [3]. If the patient complains of classic pains in the lower extremities when walking, it is necessary to conduct tests not only for ischemia, but also for neuropathy in the legs, since the latter can cause similar clinical symptoms [4].

In a number of studies it has been demonstrated that an elevation in the concentration of glycated hemoglobin up to $1 \%$ increases the risk of developing PAD by $28 \%$ [5]. Approximately $25 \%$ of patients with DM suffer from chronic arterial insufficiency and neuropathy contributes to the clinical picture of trophic changes in the leg in $80 \%$ of these patients [6].

The pathogenesis of the development of critical lower limb ischemia in patients with DM is quite complicated. Initially, patients with DM develop atrophy of the connective tissues. At the same time, the proliferation of skin fibroblasts is reduced [7]. Further, in the presence of an inflammatory process or minimal limb injury, increases the production of matrix metalloproteinases, which leads to a disruption in the synthesis of collagen fibers [8]. Against the background of the initial changes, hyperglycemia contributes to increased production of superoxide radical, which damages the vascular endothelium. This leads to the suppression of NO, and, accordingly, retreatment in these patients. The absence of angiogenesis during the repair phase slows the healing of wounds in the leg [9]. Subsequently, the number of proteases and cytokines in the wound increases and this intensifies damage of the small vessels of the leg.

Due to the presented mechanism, it is quite difficult to differentiate the primary cause of the development of critical ischemia - micro- or macroangiopathy. Damage develop in vascular system in all area of inflammatory changes. Due to this in patients with DM changes in the arteries of the lower leg are more often diagnosed, which does not allow for adequate revascularization and reduced macroangiopathy. A decrease in ankle-brachial index (ABI) to 0.50 in patients with diabetes in case of moderate stenosis of the main arteries often already leads to the need for amputation [10]. This is primarily associated with a high risk of migration of blood cells into the damaged area, which leads to micro and macro thrombosis $[1,11]$. 
By itself, an increase in blood glucose levels reduces the ABI in patients even with minimal manifestations of PAD. Approximately $30 \%$ of patients do not have an adequate assessment of the vascular bed due to the presence of neuropathy, which reduces clinical manifestations until the onset of critical lower limb ischemia [4]. It should be noted that in patients with diabetes, the distal extremities (lower leg arteries) are more often affected, unlike patients without this disease. In smoking patients the risks of developing PAD increase by 3.5 times in men and 8.6 times in women compared to non-smokers [12]. Moreover, high amputation in this lesion has to be performed 5-15 times more often than in patients without diabetes [13].

In the clinical picture of PAD in diabetes, the same factors can be traced as for patients without diabetes. However, in most cases, there is a more distal level of damage that affects the tibial arteries [14]. DM itself enhances the inflammatory response in vascular cells and leads to their alteration. All patients with PAD have an abnormal increase in protein $C$, which indicates chronic inflammation. In individuals with diabetes, the values of this protein are often higher in comparison with patients without it [15]. Protein $\mathrm{C}$ is a risk factor for thrombosis; it enhances the procoagulant activity of hemostasis due to increased excretion of tissue factors [16]. Also, its effect is associated with the suppression of NO and plasminogen-1 activation inhibitor $[13,17]$.

Due to the violation of NO-mediated vasodilation, diabetes leads to severe endothelial dysfunction [18]. Of the mechanisms of this lesion, a decrease in the concentration of $\mathrm{NO}$ and a violation of its bioavailability for cells should be noted. This is achieved both due to impaired cell susceptibility to glucose, and due to the increased content of lipoproteins in the blood of patients with diabetes [19]. Also in the vessels there is an increase in vasoconstriction due to the synthesis of endothelin-1, impaired migration of the ovary muscle cells and activation of cytokines. All this enhances atherogenesis [20]. The altered structure of atherosclerotic plaques in patients with diabetes is considered a consequence of the induction of hyperglycemia of apo- ptosis of smooth muscle cells of the arterial wall, which leads to a higher frequency of their destruction and violation of the integrity of the capsule [21]. The results of surgical revascularization in patients with diabetes depend on many factors: concomitant diseases, the presence of trophic changes in the legs, neuropathy and human immune status [22]. A high level of glycated hemoglobin also increases the risks of the distal lesion and worsens the results of revascularization in situations where it is possible, and the worse long-term results in such a situation are described for both shunt operations and endovascular interventions [23].

For patients with diabetes, it is extremely important to change the lifestyle after revascularization. This allows to affect the pathophysiological changes leading to PAD. Increased physical activity, weight loss, normalization of glucose levels, adequate therapy aimed at reducing blood atherogenicity can improve long-term results of the intervention [24]. An individual selection of the method of surgical intervention, taking into account comprehensive features, the state of health of a patient with diabetes is the most important point in treatment. In this category of patients, the incidence of arthrosis (or arthritis) of the knee joint is high, in connection with this, the results of surgical revascularization in the long term are better, in comparison with endovascular procedures. Until recently, it was believed that with proximal femoral artery damage, stenting is the surgery of choice, however, recent studies show the best long-term results of bypass surgery in patients with both proximal and distal lesions of the lower limb arteries [13].

A large retrospective study examined the effects of fasting glucose on long-term surgical outcomes. Patients were divided into 2 groups: glucose level for therapy in normal values and inadequate hypoglycemic therapy. According to the study, avoidance from restenosis after 1 year of observation in group 1 was $46 \%$, in $2-16 \%$. The same pattern was observed in the effect on the frequency of limb amputation. In this case, the appointment of insulin in the postoperative period and the normalization of glucose did not lead to an improvement in long-term 
results. The authors concluded that an adequate metabolic status of an organism during an intervention is the best predictor of long-term results [25].

Critical ischemia of the lower extremities (CILE) in patients with diabetes develops more often than in people with occlusive lesions of the lower extremities without diabetes. A number of researchers demonstrate the incidence of diabetes in patients hospitalized for CILE as high as $76 \%$ [26]. To date, it is recommended that arteries be reconstructed in patients with diabetes with an estimated shunt patency of over $75 \%$ for 1 year [27]. Often, patients with CILE on the background of diabetes require more than one intervention. Regardless of tactics simultaneous reconstruction of several levels of the arteries of the lower extremities or sequential operations in these regions give a high probability of preserving the limb [26]. The correct comprehensive multidisciplinary approach to the surgical and medical treatment of patients with diabetes allowed us to obtain a similar incidence of complications and amputations in the long term compared with people without diabetes. In the presence of ulcerative defects or diabetic foot, the fact of revascularization is important, and not the method of treatment of the patient. Healing of trophic defects and preservation of the limb have similar results in patients with surgical revascularization and endovascular interventions [28].

The main goal of treating patients with CILE and diabetes is normalization of arterial inflow to the vessels of the foot using surgical and/or endovascular technologies [29]. The main problems associated with the surgical treatment of these patients are:

- a distal-diffuse form of atherosclerotic lesion, which does not allow performing radical interventions with a good long-term distant result;

- violation of microcirculation and microangiopathy;

- increased risks of infection of a surgical wound;

- lack of adequate collateral blood supply due to the high growth rate of atherosclerotic plaques [30].

Based on the above features, for a long time patients with diabetes have been denied surgical treatment, only in recent years the number of reconstructive operations in this category of patients has begun to increase worldwide [31]. Currently, reconstructive methods are the operation of choice in PAD, even in patients with diabetes.

In the presence of a distal receiving bed, patients with diabetes need and justified to perform shunt operations on the femoral-tibial segment. Patency of shunts after 5 years in such patients reaches $57-93 \%$ [32]. Unfortunately, satisfactory results are shown only for auto-veins. Synthetic materials in patients with diabetes are prone to the rapid growth of neo-intima in the anastomotic zone. This led to the formation of shunt thrombosis and relapse of ischemia [33].

To date, it is generally accepted that the presence of at least one passable artery on the lower leg is an acceptable outflow pathway for performing reconstructive surgery [34]. The results of distal bypass operations vary widely in the literature. F.M. Pomposelli et al. [35] presented the experience of treating more than 1000 patients with revascularization at the level of the dorsal artery of the foot for 10 years. The primary patency of shunts was registered at the level of $56.8 \%$, the secondary $62.7 \%$. Other authors reported that after a year the patency of such shunts was only $58.1 \%$, and after 3 years $-39.5 \%$ [36]. As can be seen from these reports, the results of such interventions vary significantly, but they allow you to save the limb and/or heal the trophic arterial ulcer.

The main objective for the treatment of trophic diabetic ulcers is the restoration of blood flow in the foot. In most patients with a clinic of trophic ulcers, lesions of the superficial femoral artery (SFA), popliteal artery (PA) and tibial arteries (TA) were noted. With the defeat of the latter, open surgical interventions are severely limited in technical performance. Endovascular interventions are complex due to the long occlusions that are observed in these patients $(150-300 \mathrm{~mm})$. For greater convenience, the "passage" of occlusion by the conductor uses retrograde tibial access. Of the minuses of the approach, an increase in the area of the ulcer should be noted if the recanalization is not successful. Often, another ulcer 
forms in the access area, as access is essentially a violation of the integrity of the skin, and there is no adequate perfusion in this case.

In modern artery surgery, patients with diabetes increasingly use the concept of angiosomes. Due to the accumulated practical experience, areas have been identified that are supplied with various TA. Based on the data obtained, an isolated arterial revascularization is performed, which is responsible for this area. Due to normalization of blood flow, it is in the angiosomal region that the healing rate of trophic ulcers increases and the frequency of amputations decreases [37]. It is worth noting that X-ray endovascular methods allow you to save the limb on average in $86 \%$ of cases, while it is enough to perform revascularization of one artery. In diabetes mellitus, the revascularization by the presented method has higher technical success in comparison with patients without diabetes and distal lesions of the arteries of the lower extremities [38]. In an experimental study, it was shown that revascularization based on the angiosomal approach can lead to "robbing" of other parts of the leg and reduce perfusion in them [39]. Thus, it cannot be argued that endovascular revascularization is by far the most effective treatment method, it is probably one of the key tools for healing trophic ulcers and preserving the limb.

It is important to note that in TA, only angioplasty should be used predominantly. Special cylinders $20-30 \mathrm{~cm}$ long have been developed, which allows revascularization of long stenoses and occlusions. The use of stents is justified only in complicated cases (dissection, residual stenosis of more than 50\%). Given the fact that TAs have a diameter of $2.0-3.5 \mathrm{~mm}$, coronary balloon expandable stents are used in case of need for stenting. Large randomized trials demonstrate that the use of drug-coated cylinders gives better long-term results compared to simple stenting [40]. One study demonstrated a lower rate of amputation in the absence of a stent in TA[41]. Modern devices for atheroectomy did not show significant positive results in the treatment of patients of this category; on the contrary, the implementation of endovascular atheroctomy led to an increase in the number of thromboses of the reconstructed artery $[42,43]$.

Despite the achievements of endovascular treatment methods, bypass surgery remains the best reconstruction method in terms of long-term results [44]. Arterial bypass grafting of the lower extremities has an increased risk of developing transoperative complications (myocardial infarction or stroke). At the same time, the two-year survival rate after open surgery was higher [45]. In some cases, the possibility of performing a shunt operation is described even in situations where endovascular methods have proven to be ineffective. The main factor in the impossibility of reconstruction is the lack of an adequate vein on the legs for the formation of a shunt. An adequate diameter of a filled vein is considered to be $3.5-5.0 \mathrm{~mm}$, while the best longterm results are observed when using one vein, in comparison with the formation of a shunt from several sections or veins from two legs. When using a single vein, the frequency of thrombosis in the first 30 days was less than $2 \%$, and patency during the year was above $90 \%$ [46].

In one study [47], surgery was performed using a microscope, which allowed the shunting of arteries with a diameter of less than $2 \mathrm{~mm}$. Revacularization of the two leg arteries was performed in only $9.6 \%$ of cases. In the presence of a site of vein hypoplasia, resection and reversion were performed so that the site of narrowing was in the distal direction. The authors formed a "natural" decrease in diameter in the anastomotic zone. This technique made it possible to obtain $72.6 \%$ possibility of the shunt for 1 year and about $60 \%$ by the 4 th year of observation. The main task of revascularization of the arteries of the lower extremities is the restoration of adequate perfusion in the tissues of the foot. With critical ischemia, the perfusion pressure of oxygen decreases to about $20 \mathrm{mmHg}$. Art. The only objective method for restoring blood flow is considered to be an increase in oxygen pressure after revascularization. 
The level of transcutaneous oxygen tension (TCT) is today considered a predictor of wound healing, as well as a criterion for adequately performed lower limb revascularization. With a TCT value of $40 \mathrm{~mm} \mathrm{Hg}$ and higher, the trophic ulcer heals without additional surgical intervention; most surgeons seek to achieve this indicator after reconstruction of the arteries [48]. The TCT level rises after revascularization of the lower limb, regardless of the method of surgical correction [49]. However, there are a number of differences. With isolated arterial recanalization, perfusion often improves only in the region of revascularized angiosoma, with artery bypass grafting, an increase in TCTs is also observed in other angiosomes, this is especially well seen with a normally functioning plantar arch [50].

An increase in the frequency of use of the hybrid approach to surgical treatment to date has demonstrated that after initial shunting with an inadequate distal bed (on the foot), repeated angioplasty showed a higher perfusion rate and TCT level during recanalization of the foot arteries than with isolated endovascular treatment [51].

When describing the surgical treatment of PAD in patients with diabetes, all authors pointed to the need for distal reconstructions. Indeed, in practice, people with diabetes are quite rare in whom the cause of severe lower limb ischemia was the defeat of the aortic-femoral segment. According to various authors, lesions of the iliac arteries in patients with diabetes were found in no more than $20 \%$ of cases, and the femoral segment was affected in $70 \%$ of cases, of which about $15 \%$ affected the common and deep femoral artery [52]. With the initial passable aortic-femoral segment, the choice of reconstruction leaves no doubt. It is necessary to restore the distal blood flow, since there are no adequate collateral paths at the level of the knee and below. Other issues arise with stenosis above the bifurcation of the femoral artery or with lesions of both the superficial and deep femoral arteries. In such patients, microcirculation often persists, however, trophic ulcers develop due to insufficient influx along the collateral path from the iliac to the femoral arteries. When blood flow is restored to the superficial femoral artery, perfusion pressure increases and there is no need to perform distal reconstructions [53]. Thus, minimally invasive procedures, such as plasty of the deep femoral artery and endarterctomy from the common femoral artery, are of interest.

Profundoplasty was described in the 60 s of the last century [54]. As an isolated procedure, they have long been used only in patients with chronic lower limb ischemia and the "lack" of adequate outflow paths to the lower legs. As an element of treatment, it is used everywhere when performing femoral-distal bypass surgery. In recent years, this surgical intervention has "revived" and changed its purpose. Most patients with aortic-femoral lesions present stenosis of the deep femoral artery (DFA). A hybrid approach to treatment involves stenting the iliac arteries and performing profundoplasty to improve collateral blood supply.

The freedom from restenosis with profundoplasty and plastic of the common femoral artery is $96 \%$ for 8 years [55]. To perform revascularization in patients with critical lower limb ischemia, it is possible to apply this method of surgical intervention, however, it is associated with a relatively high frequency of need for additional intervention in the future (freedom from amputations of $40 \%$ for 10 years in the presence of trophic changes in the leg). At the same time, within two years, limb preservation was noted in $70 \%$ of patients, which is comparable with distal reconstructions [56].

The study of frequency of repeated interventions for bifurcation of the FA demonstrated that $17-28 \%$ of patients had hemodynamically significant restenoses for 5 years [57]. A.V. Akhmetov [57] offers to perform extended profundoplasty to branches of the 3rd order, which improves long-term results and enhances collateral blood flow. Of the advantages of surgery only in the upper third of the thigh in patients with infected or potentially infected trophic ulcers, one should note lower risks of infection $(17 \%)$, which are often represented by marginal 
skin necrosis and infiltration in the surgical area, while in the presence of shunts there is $3 \%$ risk of infection $[58,59]$.

Based on the data presented in this review, it can be concluded that modern integrated approaches to the treatment of patients with peripheral arterial disease and diabetes mellitus provide adequate longterm results for limb preservation. An important point is the restoration of the achievement of the target values of the transcutaneous oxygen tension on the lower leg and foot over $40 \mathrm{~mm} \mathrm{Hg}$ after the reconstruction. None of the methods showed an "ideal" results. In this regard, we believe that comprehensive treatment is the most justified and promising for further study.

В настоящее время более 170 миллионов людей во всем мире страдают сахарным диабетом (СД). К 2030 году, по мнению большинства экспертов, число больных увеличится до 300 миллионов [1]. СД на сегодняшний день является основным фактором риска развития заболеваний периферических артерий (ЗПА) [2]. Доказано, что наличие СД увеличивает риск сосудистых осложнений в 5 раз относительно больных без него. В связи с этим всем больным с СД необходимо проводить диагностические исследования всех сосудистых артериальных бассейнов при поражении хотя бы одного из них. Такой подход способствует уменьшению частоты осложнений от хирургических вмешательств [3]. При жалобах больного на классические боли в нижних конечностях при ходьбе необходимо проводить тесты не только на ишемию, но и на нейропатию в ногах, так как последняя способна вызывать схожую клиническую симптоматику [4].

В ряде исследований доказано, что при увеличении уровня гликированного гемоглобина на $1 \%$ риск развития ЗПА увеличивается на 28\% [5]. Примерно у $25 \%$ больных с СД развивается хроническая артериальная недостаточность, и у $80 \%$ из этих больных в клиническую картину трофи- ческих изменений на ноге вносит вклад нейропатия [6].

Патогенез развития критической ишемии нижних конечностей у больных с СД достаточно сложен. Первоначально у больных на фоне СД развивается атрофия соединительной ткани. При этом снижается пролиферация фибробластов кожи [7]. Далее, при наличии воспалительного процесса или минимальной травмы конечности, увеличивается продукция матриксных металлопротеиназ, что приводит к нарушению синтеза коллагеновых волокон [8]. На фоне первичных изменений гиперкликемия способствует повышенной выработке супероксидрадикала, который повреждает сосудистый эндотелий. Это приводит к подавлению NO, а соответственно, возодилатации у данных больных. Отсутствие в этапе репарации ангиогенеза замедляет заживление раны на ноге [9]. В дальнейшем в ране увеличивается число протеаз и цитокинов, за счет гиперстимуляции которых усиливается повреждение мелких сосудов ноги.

За счет представленного механизма сложно дифференцировать первичную причину развития критической ишемии - микро- или макроангиопатия. Происходит повреждение всей сосудистой системы в области воспалительных изменений. У больных с СД за счет этого чаще диагностируются изменения в артериях голени, что не позволяет выполнить адекватную реваскуляризацию и уменьшить макроангиопатию. Снижение ЛПИ до 0,50 у больных с СД на фоне умеренных стенозов магистральных артерий уже зачастую приводит к необходимости выполнения ампутации [10]. Это связано, в первую очередь, с высоким риском миграции форменных элементов крови в поврежденный участок, что приводит к микрои макротромбозу $[1,11]$.

Само по себе повышение уровня глюкозы в крови снижает показатель ЛПИ у больных даже с минимальными проявлениями ЗПА. Примерно у $30 \%$ больных не происходит адекватной оценки сосудистого русла из-за наличия нейропатии, которая снижает клинические проявления до мо- 
мента наступления критической ишемии нижних конечностей [4]. Необходимо отметить, что при СД у больного чаще поражаются дистальные отделы конечностей (артерии голени), в отличие от больных без данного заболевания. Если больной с СД курит, то риски развития ЗПА увеличиваются в 3,5 раза у мужчин и в 8,6 раз у женщин в сравнении с некурящими [12]. При этом высокую ампутацию при данном поражении приходится выполнять в 5-15 раз чаще, чем у больных без СД [13].

В клинической картине ЗПА при СД прослеживаются те же факторы, что и для больных без СД. Однако в большинстве случаев отмечается более дистальный уровень поражения, поражающий берцовые артерии [14]. СД сам по себе усиливает воспалительные реакции в сосудистых клетках и приводит к их альтерации. У всех больных с ЗПА отмечается аномальное повышение уровня протеина $\mathrm{C}$, что свидетельствует о хроническом воспалении. У лиц с СД значения данного белка зачастую выше в сравнении с больными без него [15]. Протеин С является фактором риска тромбообразования, он усиливает прокоагулянтную цель гемостаза за счет усиления экскреции тканевых факторов [16]. Также его действие связывают с подавлением NO и ингибитора активации плазминогена-1 [13, 17$]$.

За счет нарушения NO-опосредованной вазодилатации СД приводит к выраженной эндотелиальной дисфункции [18]. Из механизмов данного поражения следует отметить снижение концентрации NO, нарушение его биодоступности для клеток. Это достигается как за счет нарушения восприимчивости клеток к глюкозе, так и за счет повышенного содержания липопротеинов в крови больных с СД [19]. Также в сосудах происходит усиление вазоконструкции за счет синтеза эндотелина-1, нарушение миграции гладкомышечных клеток и активация процитокинов. Все это усиливает атерогенез [20]. Измененную структуру атеросклеротических бляшек у больных с СД считают следствием индукции гипергликемии апоптоза гладкомышечных клеток стенки артерий, что приводит к большей частоте их деструкции и нарушению целостности капсулы [21].

Результаты хирургической реваскуляризации у больных с СД зависят от множества факторов: сопутствующих заболеваний, наличия трофических изменений на ногах, нейропатии и иммунного статуса человека [22]. Высокий уровень гликированного гемоглобина также увеличивает риски дистальной формы поражения и ухудшает результаты реваскуляризации в ситуациях, когда она возможна, причем более худшие отдаленные результаты в такой ситуации описаны как для шунтирующих операций, так и для эндоваскулярных вмешательств [23].

Для больных с СД крайне важным является изменение образа жизни после реваскуляризации. Это позволяет также воздействовать на патофизиологические изменения, приводящие к ЗПА. Увеличение физической активности, снижение массы тела, нормализация уровня глюкозы, адекватная терапия, направленная на снижение уровня атерогенности крови, позволяют улучшить отдаленные результаты вмешательства [24].

Индивидуальный подбор метода хирургического вмешательства с учетом всесторонних особенностей состояния здоровья больного с СД является наиболее важным моментом в лечении. У данной категории больных высока встречаемость артроза (или артрита) коленного сустава, в связи с этим результаты хирургической реваскуляризации в отдаленном периоде лучше в сравнении с эндоваскулярными процедурами. До недавнего времени считалось, что при проксимальном поражении бедренной артерии операцией выбора является стентирование, однако последние исследования демонстрируют лучшие отдаленные результаты шунтирующих операций у больных как с проксимальным, так и с дистальным поражением артерий нижних конечностей [13].

В крупном ретроспективном исследовании было изучено влияние уровня глюкозы натощак 
на отдаленные результаты хирургического лечения. Больные были разделены на 2 группы: уровень глюкозы на терапии в нормальных значениях и неадекватная сахароснижающая терапия. По данным автором свобода от рестеноза через 1 год наблюдения в 1-й группе составила $46 \%$, во 2-й - 16\%. Такая же закономерность отмечена во влиянии на частоту ампутации конечности. При этом назначение инсулина в послеоперационном периоде и нормализация уровня глюкозы не приводило к улучшению отдаленных результатов. Авторы сделали вывод, что адекватный метаболический статус организма во время вмешательства — лучший предиктор отдаленных результатов [25].

Критическая ишемия нижних конечностей (КИНК) у больных с СД развивается чаще, чем у лиц с окклюзионным поражением нижних конечностей без диабета. Ряд исследователей демонстрируют частоту встречаемости СД у больных, госпитализированных по поводу КИНК, достигающую 76\% [26]. На сегодняшний день рекомендовано выполнять реконструкцию артерий у пациентов с СД при предполагаемой проходимости шунта в течение 1 года свыше 75\% [27]. Зачастую у больных с КИНК на фоне СД требуется более одного вмешательства. Независимо от тактики одномоментная реконструкция нескольких уровней артерий нижних конечностей или последовательные операции на этих регионах дают высокую вероятность сохранить конечность [26]. Правильный комплексный междисциплинарный подход к хирургическому и медикаментозному лечению больных с СД позволил получить схожую частоту осложнений и ампутаций в отдаленном периоде в сравнении с лицами без СД. При наличии язвенных дефектов или диабетической стопы важен сам факт реваскуляризации, а не метод лечения больного. Заживание трофических дефектов и сохранение конечности имеют схожие результаты у больных с хирургической реваскуляризацией и эндоваскулярными вмешательствами [28].
Основной задачей лечения больных с ХИНК и СД считают нормализацию артериального притока к сосудам стопы с помощью хирургических и/или эндоваскулярных технологий [29].

Основными проблемами, с которыми связывают хирургическое лечение данных пациентов, считают:

- дистально-диффузная форма атеросклеротического поражения, которая не позволяет выполнять радикальные вмешательства с хорошим отдаленным результатом;

- нарушение микроциркуляции и микроангиопатия;

- повышенные риски инфицирования хирургической раны;

- отсутствие адекватного коллатерального кровоснабжения за счет высокой скорости роста атеросклеротических бляшек [30].

Исходя из вышеперечисленных особенностей длительное время больным СД отказывали в хирургическом лечении, только последние годы во всем мире начинает увеличиваться количество реконструктивных операций у данной категории больных [31]. В настоящее время реконструктивные методы являются операцией выбора при ЗПА даже у больных с СД.

При наличии дистального принимающего русла больным СД необходимо и оправдано выполнять шунтирующие операции на бедреннотибиальном сегменте. Проходимость шунтов через 5 лет у таких больных достигает 5793\% [32]. К сожалению, удовлетворительные результаты продемонстрированы только для аутовены. Синтетические материалы у больных СД подвержены быстрому разрастанию неоинтимы в зоне анастомоза. Это приводило к формированию тромбоза шунта и рецидива ишемии [33].

На сегодняшний день общепринято, что наличие хотя бы одной проходимой артерии на голени является приемлемым путем оттока для выполнения реконструктивной операции [34].

Результаты дистальных шунтирующих операций сильно различаются в литературе. F.M. Pom- 
poselli et al. представили опыт лечения свыше 1000 больных с реваскуляризацией на уровне тыльной артерии стопы в течение 10 лет. Первичная проходимость шунтов зарегистрирована на уровне $56,8 \%$, вторичная - $62,7 \%$ [35]. Другие авторы доложили, что через год проходимость подобных шунтов составила всего $58,1 \%$, а через 3 года - 39,5\% [36]. Как видно из данных сообщений, результаты таких вмешательств в значительной мере разнятся, однако они позволяют сохранить конечность и/или залечить трофическую артериальную язву.

Основной задачей для лечения трофических диабетических язв является восстановление кровотока по стопе. У большинства больных с клиникой трофических язв отмечено поражение поверхностной бедренной артерии (ПБА), подколенной артерии (ПкА) и берцовых артерий (БА). При поражении последних открытые хирургические вмешательства сильно ограничены в техническом исполнении. Эндоваскулярные вмешательства сложны за чет большой длины окклюзий, которые наблюдаются у данных пациентов (150-300 мм). Для большего удобства «прохождения» окклюзии проводником используют ретроградный тибиальный доступ. Из минусов подхода следует отметить увеличение площади язвы, если реканализация будет не успешной. Часто в зоне доступа формируется еще одна язва, т.к. доступ по сути является нарушением целостности кожных покровов, а адекватной перфузии в данном случае нет.

В современной хирургии артерий больных с СД все больше и больше используют понятие ангиосом. За счет накопленного практического опыта выявлены участки, которые кровоснабжаются различными БА. На основании полученных данных выполняют изолированную реваскуляризацию артерии, отвечающую за данный участок. За счет нормализации кровотока именно в ангиосомной области увеличивается скорость заживления трофической язвы и снижается частота ампутаций [37].
Стоит отметить, что рентгенэндоваскулярные методы позволяют сохранить конечность в среднем в $86 \%$ случаев, при этом достаточно выполнить реваскуляризацию одной артерии. При СД реваскуляризация представленным методом имеет более высокий технический успех в сравнении с больными без СД и дистальным поражением артерий нижних конечностей [38]. В ходе экспериментального исследования было показано, что реваскуляризация на основании ангиосомного подхода может приводить к «обкрадыванию» других участков голени и уменьшать перфузию в них [39]. Таким образом, нельзя утверждать, что эндовакулярная реваскуляризация на сегодняшний день - наиболее эффективный метод лечения. Вероятно, она является одним из ключевых инструментов для заживления трофических язв и сохранения конечности.

Важно отметить, что в БА преимущественно следует применять только ангиопластику. Разработаны специальные баллоны длинной 20$30 \mathrm{~cm}$, что позволяет реваскуляризировать длинные стенозы и окклюзии. Применение стентов оправдано только в осложненных случаях (диссекция, остаточный стеноз более $50 \%$ ). Учитывая тот факт, что БА имеют диаметр 2,0-3,5 мм, в случае потребности в стентировании используют коронарные баллоно-расширяемые стенты. Крупные рандомизированные исследования демонстрируют то, что использование баллонов с лекарственным покрытием дает лучшие отдаленные результаты в сравнении с простым стентированием [40]. В одном исследовании продемонстрирована меньшая частота ампутаций при отсутствии стента в БА [41]. Современные устройства для атероэктомии не показали значимых положительных результатов в лечении больных данной категории, наоборот, выполнение эндоваскулярной атероэктомии приводило к увеличению числа тромбозов реконструированной артерии $[42,43]$.

Несмотря на достижения эндоваскулярных методов лечения шунтирующие операции оста- 
ются лучшим методом реконструкции с точки зрения отдаленных результатов [44]. Выполнение шунтирования артерий нижних конечностей имеет повышенный риск развития переоперационных осложнений (инфаркта миокарда или инсульта). В то же время двухлетняя выживаемость после открытой операции была выше [45]. В ряде случаев описана возможность выполнения шунтирующей операции даже в ситуациях, когда эндоваскулярные методы оказались неэффективными. Главный фактор невозможности проведения реконструкции - отсутствие адекватной вены на ногах для формирования шунта. Адекватным диаметром наполненной вены считается 3,5-5,0 мм, при этом лучшие отдаленные результаты наблюдаются при использовании одной вены, в сравнении с формированием шунта из нескольких участков или вен с двух ног. При использовании единой вены частота тромбоза в первые 30 дней составила менее 2\%, а проходимость в течение года - выше 90\% [46].

В одном исследовании хирургическое вмешательство выполняли с помощью микроскопа, это позволило шунтировать артерии диаметром менее 2 мм. Реваскуляризацию двух артерий голени выполняли всего в 9,6\% случаев. При наличии участка гипоплазии вены была выполнена резекция и реверсия таким образом, чтобы участок сужения находился в дистальном направлении. Авторы формировали «естественное» уменьшение диаметра в зоне анастомоза. Такая техника позволила получить 72,6\% проходимость шунта в течение 1 года и около 60\% к 4-му году наблюдения [47].

Основной задачей реваскуляризации артерий нижних конечностей является восстановление адекватной перфузии в тканях стопы. При критической ишемии перфузионное давление кислорода снижается примерно до 20 мм рт. ст. Единственным объективным методом восстановления кровотока считают увеличение давления кислорода после реваскуляризации. Уровень транскутанного напряжения кислорода (ТНК) на сегодняшний день считают предиктором заживления раны, а также критерием адекватно выполненной реваскуляризации нижней конечности. При значении ТНК 40 мм рт. ст. и выше трофическая язва заживает без дополнительного хирургического вмешательства, большинство хирургов стремится достигнуть данного показателя после реконструкции артерий [48].

Уровень ТНК повышается после реваскуляризации нижней конечности вне зависимости от метода хирургической коррекции [49]. Однако существует ряд отличий. При изолированной реканализации артерии зачастую улучшается перфузия только в области реваскуляризированной ангиосмы, при шунтировании артерии отмечено увеличение ТНК также в других ангиосомах, это особенно хорошо прослеживается при нормально функционирующей плантарной дуге [50].

Увеличение частоты использования гибридного подхода к хирургическому лечению на сегодняшний день продемонстрировало, что после первично выполненного шунтирования при неадекватном дистальном русле (на стопе) повторная ангиопластика показала большую скорость перфузии и уровень ТНК при реканализации артерий стопы, чем при изолированном эндоваскулярном лечении [51].

При описании хирургического лечения ЗПА у больных СД все авторы указывали на необходимость выполнения дистальных реконструкций. Действительно в практике достаточно редко встречаются лица с СД, у которых причиной тяжелой ишемии нижних конечностей служило поражение аорто-бедренного сегмента. По данным разных авторов, поражение подвздошных артерий у больных с СД встречалось не более чем в $20 \%$ случаев, а бедренный сегмент поражался - в 70\% случаев, из них около $15 \%$ затрагивали общую и глубокую бедренную артерию [52].

При исходно проходимом аорто-бедренном сегменте выбор реконструкции не оставляет сомнений. Необходимо восстановить дистальный 
кровоток, так как отсутствуют адекватные коллатеральные пути на уровне колена и ниже. Другие вопросы возникают при стенозах выше бифуркации бедренной артерии или при поражении как поверхностной, так и глубокой артерий бедра.

У таких больных зачастую микроциркуляция сохраняется, однако трофические язвы развиваются за счет недостаточного притока по коллатеральному пути из подвздошных до бедренных артерий. При восстановлении кровотока до поверхностной бедренной артерии перфузионное давление увеличивается и отсутствует необходимость выполнять дистальные реконструкции [53]. Таким образом, интерес представляют минимально инвазивные процедуры, такие как пластика глубокой артерии бедра и эндарктеркэтомия из общей бедренной артерии.

Профундопластика описана в 60-е годы прошлого столетия [54]. Как изолированная процедура они долгое время применялась только у больных с хронической ишемией нижних конечностей и «отсутствием» адекватных путей оттока на голени. Как элемент лечения ее применяют повсеместно при выполнении бедренно-дистальных шунтирований. В последние годы данное хирургическое вмешательство «возродилось» и изменило свое назначение. У большинства больных с аорто-бедренным поражением присутствуют стенозы глубокой артерии бедра (ГБА). Гибридный подход к лечению включает стентирование подвздошных артерий и выполнение профундопластики для улучшения коллатерального кровоснабжения.

Свобода от рестеноза при профундопластике и пластике общей бедренной артерии составляет 96\% в течение 8 лет [55]. Для выполнения реваскуляризации у больных с критической ишемией нижних конечностей возможно применять данный метод хирургического вмешательства, однако он сопряжен с относительно высокой частотой потребности в дополнительном вмешательстве в дальнейшем (свобода от ампутаций 40\% в течение 10 лет при наличии трофических изменений на ноге). В то же время в течение двух лет сохранение конечности отмечено у 70\% больных, что сопоставимо с дистальными реконструкциями [56].

Отдельные авторы изучали частоту повторных вмешательств на бифуркации бедренной артерии. Было продемонстрировано, что $17-28 \%$ больных имели гемодинамически значимые рестенозы в течение 5 лет [57]. А.В. Ахметов предлагает выполнять протяженную профундопластику до ветвей 3-го порядка, что улучшает отдаленные результаты и усиливает коллатеральный кровоток [57]. Из преимуществ хирургического вмешательства только в верхней трети бедра у больных с инфицированными или потенциально инфицированными трофическими язвами следует отметить меньшие риски инфекции (17\%), которые зачастую представлены краевыми некрозами кожи и инфильтрацией в зоне операции, в то время как при наличии шунтов имеется $3 \%$ риск его инфицирования [58, 59].

Исходя из представленной информации можно сделать вывод, что современные комплексные подходы к лечению больных с заболеваниями периферических артерий и сахарным диабетом позволяют получить адекватные отдаленные результаты по сохранению конечности. Важным моментом является восстановление достижения целевых значений транскутанного напряжения кислорода на голени и стопе свыше 40 мм рт. ст. после выполненной реконструкции. Ни один из методов не продемонстрировал «идеальных» результатов. В связи с этим считаем, что комплексное лечения является наиболее оправданным и перспективным для дальнейшего изучения.

\section{References / Библиографический список}

1. Armstrong EJ, Waltenberger J, Rogers JH. Percutaneous coronary intervention in patients with diabetes: current concepts and futuredirections. J Diabetes Sci Technol. 2014;8: 581—589. DOI: 10.1177/1932296813517058

2. Armstrong EJ, Rutledge JC, Rogers JH. Coronary artery revascularizationin patients with diabetes mellitus. Circulation. 2013;128: 1675-85. 
3. Hirsch AT, Hartman L, Town RJ et al. National health care costs of peripheral arterial disease in the Medicare population. Vasc Med. 2008;13: 209-15. DOI: 10.1177/1358863X08089277

4. Marso SP, Hiatt WR. Peripheral arterial disease in patients with diabetes. J Am Coll Cardiol. 2006;47: 921—9. DOI: $10.1016 /$ j.jacc.2005.09.065

5. Selvin E, Marinopoulos S, Berkenblit G, et al. Meta-analysis: glycosylated hemoglobinand cardiovascular disease in diabetes mellitus. Ann Intern Med 2004;141: 421-31. DOI: 10.7326/0003-4819-141-6-200409210-00007

6. American Diabetes Association. Economic cost of diabetes in the US in 2007. Diabetes Care. 2008;31: 596-615.

7. Lateel H, Stevens MJ, Varni J. All transretinoic acid suppresses matrix metalloproteinase activity and increases collagen synthesis in diabetic human skin in organ culture. Am J Pathol. 2004;165: 167-74.

8. Varani J, Warner RL, Gharaee-kermani M, et al. Vitamin A antagonizes decreased cell growthand elevated collagen-degrading matrix metalloproteinases and stimulates collagen accumulation in naturally aged human skin. J Invest Dermatol. 2000;114: 480 -6.

9. Wear-Magi Hik, lee J, Conejero A, et al. Use of topical RAGE in diabetic wounds increase end neovascularization and granular tissue formation. Ann Plast Surg. 2004;52: 12-22.

10. Marston WA, Davies SW, Armstrong B, et al. Natural history of limbs with arterialinsufficiency and chronic ulceration treated with revascularization. J. Vasc Surg. 2006;44: 108-14.

11. Schaper NC, Nabuurs-Franssen MH, Huijberts MS. Peripheral vascular disease and type 2 diabetes mellitus. Diabetes Metab Res Rev. 2000;16 Suppl 1: S11-S15.

12. Kannel WB, McGee DL. Update on some epidemiologic features of intermittent claudication: the Framingham Study. J Am Geriatr Soc. 1985;33: 13-8.

13. American Diabetes Association. Peripheral arterial disease in people with diabetes. Diabetes Care. 2003;26: 333341. DOI: $10.2337 /$ diacare.26.12.3333

14. Haltmayer M, Mueller T, Horvath W, et al. Impact of atherosclerotic risk factors on the anatomical distribution of peripheral arterial disease. Int Angiol. 2001;20: 200-7.

15. Ridker PM, Cushman M, Stampfer MJ, et al. Plasma concentration of C-reactive protein and risk of developing peripheral vascular disease. Circulation. 1998;97: 425-8.

16. Cermak J, Key NS, Bach RR, et al. C-reactive protein induces human peripheral blood monocytes to synthesize tissue factor. Blood. 1993;82: 513-20.

17. Vinik AI, Erbas T, Park TS, et al. Platelet dysfunction in type 2 diabetes. Diabetes Care. 2001;24: 1476-85.

18. Williams SB, Cusco JA, Roddy MA, et al. Impaired nitric oxide-mediated vasodilation in patients with non-insulindependent diabetes mellitus. J Am Coll Cardiol. 1996; 27: $567-74$.
19. De Vriese AS, Verbeuren TJ, Van de Voorde J, et al. Endothelial dysfunction in diabetes. $\mathrm{Br} J$ Pharmacol. 2000;130: 963-74.

20. Inoguchi T, Li P, Umeda F, et al. High glucose level and free fatty acid stimulate reactive oxygen species production through protein kinase $\mathrm{C}$-dependent activation of NAD(P)H oxidase in cultured vascular cells. Diabetes. 2000;49: 1939-45.

21. Geng YJ, Libby P. Progression of atheroma: a struggle between death and procreation. Arterioscler Thromb Vasc Biol. 2002;22: 1370 - 80.

22. Forsythe RO, Jones KG, Hinchliffe RJ. Distal bypasses in patients with diabetes and infrapopliteal disease: technical considerations to achieve success. Int $J$ Low Extrem Wounds. 2014;13: 347-362.

23. Singh S, Armstrong EJ, Sherif W, et al. Association of elevated fasting glucose with lower patency and increased major adverse limb events among patients with diabetes undergoing infrapopliteal balloon angioplasty. Vasc Med. 2014;19: 307-14. DOI: 10.1177/1358863X14538330]

24. Reynolds K, He J. Epidemiology of the metabolic syndrome. Am J Med Sci. 2005;330: 273-9. DOI: 10.1097/000 00441-200512000-00004

25. BeckmKullo IJ, Bailey KR, Kardia SL, et al. Ethnic differences in peripheral arterial disease in the NHLBI Genetic Epidemiology Network of Arteriopathy (GENOA) study. Vasc Med. 2003;8: 237-42.

26. Dick F, Diehm N, Galimanis A, et al. Surgical or endovascular revascularization in atients with critical limb ischemia: influence of diabetes mellitus on clinical outcome. J Vasc Surg. 2007;45: 751-61. DOI: 10.1016/j.jvs.2006.12.022]

27. Awad S, Karkos CD, Serrachino-Inglott F, et al. The impact of diabetes on current revascularisation practice and clinical outcome in patients with critical lower limb ischaemia. Eur J Vasc Endovasc Surg. 2006;32: 51-9. DOI: 10.1016/j.ejvs.2005.12.019

28. Hinchliffe RJ, Andros G, Apelqvist J, et al. A systematic review of the effectiveness of revascularization of the ulcerated foot in patients with diabetes and peripheral arterial disease. Diabetes Metab Res Rev. 2012;28 Suppl 1: 179—217. DOI: 10.1002/dmrr.2249

29. Katelnitsky II, Muradov AM. Possibilities of reconstruction and restoration of lower leg arteries during critical ischemia in patients with atherosclerotic lesions of the lower extremities. Modern problems of science and education. 2015; 2-1. URL: http://www.science-education.ru/ $\mathrm{ru} /$ article/view?id=18533

Кательниикий И.И., Мурадов А.М. Возможности реконструкции и восстановления артерий голени при критической ишемии у больных с атеросклеротическим поражением нижних конечностей // Современные проблемы науки и образования. [Электронный ресурс]. Электрон. журн. № 2-1. 
Режим доступа: http://www.science-education.ru/ ru/article/view?id=18533 (дата обращения: 01.11.2019).

30. Aslanov AD, Logvina OE, Kugotov AG. Experience in the treatment of critical lower limb ischemia on the background of diffuse damage to arteries. Angiology and Vascular Surgery. 2012;18(4): 125-7.

Асланов А.Д., Логвина О.Е., Куготов А.Г. Опыт лечения критической ишемии нижних конечностей на фоне диффузного поражения артерий // Ангиология и сосудистая хирургия. 2012. Т. 18. № 4. C. $125-127$.

31. Gavrilenko AV, Voronov DA, Kotov AE. Comprehensive treatment of patients with critical lower limb ischemia in combination with diabetes. Annals of surgery. 2014;3: $41-6$.

Гавриленко А.В., Воронов Д.А., Котов А.Э. Комплексное лечение больных с критической ишемией нижних конечностей в сочетании с сахарным диабетом // Анналы хирургии. 2014. № 3. C. $41-46$.

32. Kolobova OI, Subbotin YuG, Kozlov AV. In-situ autogenous shunting in patients with distal arterial occlusions of the lower extremities in case of diabetes mellitus. Surgery. Magazine them. N.I. Pirogov. 2011;7: 18-23.

Колобова О.И. Субботин Ю.Г. Козлов А.В. Аутовенозное шунтирование in situ у больных с дистальными артериальными окклюзиями нижних конечностей при сахарном диабете // Хирургия. Журнал им. Н.И. Пирогова. 2011. № 7. С. $18-23$.

33. Kim CY, Naidu S, Kim YH. Supermicrosurgery in parineal and soleus perforation-based free flap coverage of food defects caused by occlusive vascular disease. Plast. Reconst. Surg. 2010;126(2): 499-507.

34. Kanyushin NV, Tuvanova EP, Deryagin EV. Surgical treatment of critical lower limb ischemia in the general surgical department. Bulletin of the East Siberian Scientific Center of the Siberian Branch of the Russian Academy of Medical Sciences. 2012;4(86): 60-1.

Канюшин Н.В., Тванова Е.П., Дерягин Е.В. и др.

Хирургическое лечение критической ишемии нижних конечностей в условиях общехирургического отделения // Бюллетень Восточно-Сибирского научного центра Сибирского отделения Российской академии медицинских наук. 2012. T. 86. № 4. C. $60-61$.

35. Pomposelli FM. A decade of experience with dorsal pedis artery: analysis of outcome in more than 1000 case. J. Vase. Surg. 2003;37(2): 307-15.

36. Frankini AD, Pezella MV. Foot revascularization in patients with critical limb ischemia. Rev Port Cir Cardiotorac Vasc. 2003 Apr-Jun; 10 (2): 75—81.
37. Biancari F, Juvonen T. Angiosome-targeted lower limb revascularization for ischemic foot wounds: systematic review and meta-analysis. European journal of vascular and endovascular surgery: the official journal of the European Society for Vascular Surgery. 2014;47: 517-2.

38. Eroshkin IA. X-ray diagnostic correction of lesions of lower limb arteries in patients with diabetes mellitus and its role in the complex treatment of diabetic foot syndrome. PhD thesis of Doctor of Med. Sciences. Moscow. 2010. p.58.

Ерошкин И.А. Рентегенохиургическая коррекция поражений артерий нижних конечностей у больных с сахарным диабетом и ее роль в комплексном лечении синдрома диабетической стопы: автореф. дис. ... докт. мед. наук: 14.01.26 / Ерошкин Иван Анатольевич; 25 Центральный военный клинический госпиталь РВСН МО РФ. М., 2010. 58 с.

39. Kawarada O, Yasuda S, Nishimura K, et al. Effect of single tibial artery revascularization on microcirculation in the setting of critical limb ischemia. Circulation Cardiovascular interventions. 2014;7: 684-91.

40. Bosiers M, Scheinert D, Peeters P, et al. Randomized comparison of everolimus-eluting versus bare-metal stents in patients with critical limb ischemia and infrapopliteal arterial occlusive disease. Journal of vascular surgery. 2012;55: 390-8.

41. Rastan A, Brechtel K, Krankenberg H, et al. Sirolimuseluting stents for treatment of infrapopliteal arteries reduce clinical event rate compared to bare-metal stents: long-term results from a randomized trial. $J$ Am Coll Cardiol. 2012;60: 587-91.

42. Ambler GK, Radwan R, Hayes PD, et al. Atherectomy for peripheral arterial disease. The Cochrane database of systematic reviews. 2014;3: CD006680.

43. Piyaskulkaew C, Parvataneni K, Ballout H, et al. Laser in infrapopliteal and popliteal stenosis 2 study (LIPS2): Long-term outcomes of laser-assisted ball angioplasty versus ball angioplasty for below knee peripheral arterial disease. Catheter Cardiovasc Interv. 2015;86: 1211-8.

44. Mehaffey JH, Hawkins RB, Fashandi A. Lower extremity bypass for critical limb ischemia decreases major adverse limb events with equivalent cardiac risk compared with endovascular intervention. J Vasc Surg. 2017 Jun 24. pii: S0741—5214 (17) 31143-6.

45. Slovut DP, Lipsitz EC. Surgical technique and peripheral artery disease. Circulation. 2012;126: 1127-38.

46. Conte MS. Critical appraisal of surgical revascularization for critical limb ischemia. Journal of vascular surgery. 2013;57: 8S-13S.

47. Tanaka Y, Uemura T, Ayabe S, et al. Revisiting Microsurgical Distal Bypass for Critical Limb Ischemia J. Reconstr Microsurg. 2016;32(8): 608-14. 
48. Watanabe Y, Onozuka A, Obitsu Y, et al. Skin perfusion pressure measurement to assess improvement in peripheral circulation after arterial reconstruction for critical limb ischemia. Ann Vasc Dis. 2011;4: 235-40.

49. Yamada $\mathrm{T}$, Ohta $\mathrm{T}$, Ishibashi $\mathrm{H}$, et al. Clinical reliability and utility of skin perfusion pressure measurement in ischemic limbs - comparison with other noninvasive diagnostic methods. $J$ Vasc Surg. 2008;47: 318-23.

50. Bradbury AW, Adam DJ, Bell J, et al. Bypass versus Angioplasty in Severe Ischaemia of Leg (BASIL) trial: analysis of amputation free and overall survival by treatment received. J Vasc Surg. 2010;51: 18S-31S.

51. Mochizuki Y, Hoshina K, Shigematsu K et al. Distal bypass to a critically ischemic foot increases the skin perfusion pressure at the opposite site of the distal anastomosis. Vascular. 2016;24(4): 361-7.

52. Guo X, Shi Y, Huang X, Et al. Features analysis of lower extremity arterial lesions in 162 diabetes patients. $J$ Diabetes Res. 2013;78(1): 360—9.

53. Shinozaki N. The effectiveness of skin perfusion pressure measurements during endovascular therapy in determining the endpoint in critical limb ischemia. Intern Med. 2012; 51(12): 1527-30.

54. Leeds FH, Gilfillan RS. Importance of profunda femoris artery in the revascularization of the ischemic limb. Arch Surg. 1961;82: 25-31.
55. Malgor RD, Ricotta JJ, Bower TC, et al. Common femoral artery endarterectomy for lower-extremity ischemia: evaluating the need for additional distal limb revascularization. Ann Vasc Surg. 2012;26: 946-56.

56. Taurino M, Persiani F, Ficarelli R Et al. The Role of the Profundoplasty in the Modern Management of Patient with Peripheral Vascular Disease. Ann Vasc Surg. 2017 May 24. pii: S0890-5096 (17) 30694-5.

57. Akhmetov AV. Reconstruction of the deep femoral artery in the complex treatment of patients with chronic critical lower limb ischemia. PhD thesis. Nalchik. 2006. p.58.

Ахметов A.B. Реконструкция глубокой артерии бедра в комплексном лечении больных с хронической критической ишемией нижних конечностей: автореф. дис. ... канд. мед. наук: 14.00.27 / Ахметов Асланбек Вячеславович; ГОУ ВПО Кабардино-Балкарский государственный университет. Нальчик, 2006. 25 с.

58. Derksen WJ, Gisbertz SS, Hellings WE, et al. Predictive risk factors for restenosis after remote superficial femoral artery endarterectomy. Eur J Vasc Endovasc Surg. 2010;39: 597-603.

59. Kang JL, Patel VI, Conrad MF, et al. Common femoral artery occlusive disease: contemporary results following surgical endarterectomy. J Vasc Surg. 2008;48: $872-7$.

Correspondence Author: Tsurtsumiya Shalva Shalvovich — graduate student, Sechenov University Ministry of Health of the Russian Federation, Moscow, Russia. E-mail: ashihara@mail.ru

Ответственный за переписку: Цурцумия Шалва Шалвович - аспирант, Федеральное государственное бюджетное образовательное учреждение высшего образования Первый Московский государственный медицинский университет им. И.М. Сеченова (Сеченовский Университет) Минздрава РФ, Российская Федерация, 119146, Москва, ул. Большая Пироговская, 19 стр. 1. E-mail: ashihara@mail.ru 